\title{
ФОЛЬКЛОРНЫЕ ЭЛЕМЕНТЫ В ПОВЕСТЯХ АНДРЕЯ ПЛАТОНОВА: СТЕРЕОТИПИЧСКИЕ ЧЕРТЫ В СТРУКТУРЕ ОБРАЗА ГЛАВНОГО ГЕРОЯ Елена Михайловна КАМИНСКАЯ
}

Доктор философии по филологическим наукам (PhD)

Кафедра русского литературоведения, факультет зарубежной филологии

Национальный университет Узбекистана имени Мирзо Улугбека

Ташкент, Узбекистан

\section{АНДРЕЙ ПЛАТОНОВ ҚИССАЛАРИДА ФОЛЬКЛОР АНЪАНАЛАРИ ВА БОШ ҚАХРАМОННИНГ СТЕРЕОТИП ХУСУСИЯТЛАРИ Елена Михайловна КАМИНСКАЯ \\ Филология фанлари номзоди \\ Рус адабиетшунослиги кафедраси, хорижий филология факультети \\ Мирзо Улуғбек номидаги Ўзбекистон Миллий университети \\ Тошкент, Ўзбекистон}

\section{FOLKLORE ELEMENTS IN THE STORIES OF ANDREY PLATONOV AND STEREOTYPICAL FEATURES OF THE MAIN CHARACTER}

\section{Elena Mikhailovna KAMINSKAYA}

Candidate of Philological Sciences

Department of Russian Literary Studies

Faculty of Foreign Philology

National University of Uzbekistan named after Mirzo Ulugbek

Tashkent, Uzbekistan

UDC (Уั̆К, УДК) 81'398.2: 821.161.1Платонов

For citation (иқтибос келтириш учун):

Каминская Е.М. Фольклорные элементы в повестях Андрея Платонова: стереотипичские черты в структуре образа главного героя// Ўзбекистонда хорижий тиллар. - 2021. - № 6 (41). - C. 229-242.

\section{https://doi.org/10.36078/1644649582}

Received: October 18., 2021

Accepted: December 17, 2021

Published: December 20, 2021

Copyright (C) 2021 by author(s) and Scientific Research Publishing Inc.

This work is licensed under the Creative Commons Attribution International License (CC BY 4.0).

http://creativecommons.org/licenses/by/4.0/

\section{Open Access}

\begin{abstract}
Аннотация. Предметом настоящего исследования стали фольклорные традиции в творчестве А. Платонова. В процессе анализа повестей писателя были выявлены сказочные элементы. В повестях писателя в качестве повторяющихся элементов, благодаря которым формируется неповторимый, платоновский тип характера героя («платоновский человек»). В частности, среди фольклорных черт отмечена связь со сказочным третьим сыном. Герои в повестях писателя, в структуре характера которых отмечено наличие черт сказочного третьего сына, были условно отнесены к типу «чудака-умельца». Чудак-умелец - это герой, наделенный творческим талантом созерцать и создавать чудесные вещи. Жизнь героев-умельцев часто связана с мотивом странничества. В процессе анализа был выделен тип «героя-думальщика», обладающего положительным и отрицательным зарядом. Такое деление обусловлено критерием значимости совершаемого героем для окружающих: дума во благо или во зло человека. Понятия «дума» и «ум» выступают в повести с отрицательной характеристикой. При этом для А. Платонова важен момент утверждения зыбкости границы между добрым и злым поступком. Тип героя-думальщика, обладающий положительным зарядом был разделен на два подтипа - это герои-созерцатели (они движутся по земле на короткие
\end{abstract}


мгновения останавливаясь в том или ином пункте и вновь продолжая свой бесконечный путь) и герои-деятели. Поиск чудесного предмета совмещен в повестях с поиском невесты. В повестях два сказочных мотива - поиск невесты и испытание жениха невестой, совмещенный с мотивом борьбы-соревнования. Результатом проведенного исследования стало выделение особого типа героя «платоновского человека», соотносящегося с фольклорной традицией и воплощающего черты индивидуальноавторского стиля писателя.

Ключевые слова: повесть; фольклорная традиция; жанр сказки; третий сын; низкий герой; антагонист; фольклорный тип характера героя; стереотипность.

Аннотация. Мақолада тадқиқот предмети хисобланган А.Платонов асарларидаги фольклор анъаналари мухокама қилинган. Ёзувчи қиссаларининг тахлили жараёнида эртак жанрига хос элементлар аниқланди. Ёзувчи қиссаларида такрорланувчи бадиий унсурлар орқали қахрамоннинг ўзига хос, Платоновга хос характери шаклланади ("Платонов одами”). Хусусан, ижодкор асарларидаги образларда фольклорга хосажойиб “учинчи ўғил" мотиви билан боғлиқлик мавжуд. Ёзувчи қиссаларидаги қахрамонлар, характерларнинг тузилишида “учинчи ўғил”нинг ажойиб хусусиятлари борлиги аниқланган ва шартли равишда “тектаксимон мохир-уста" типи сифатида таснифланган. “Тектаксимон мохир-уста" - бу ғайриоддий нарсаларни кузатиш ва яратиш учун ижодий қобилиятга эга қахрамон. Мохир-уста қахрамонларнинг хаёти кўпинча мусофирлик мотиви билан боғлиқ. Тахлил жараёнида ижобий ва салбий хусусиятга эга "мутафаккир-қахрамон" тури аниқланди. Бу бўлиниш қахрамоннинг атрофдагилар учун қилаётган ишининг ахамияти мезонидан келиб чиқади. Шу билан бирга, А.Платонов учун яхшилик ва ёмонлик чегарасининг мўртлигини тасдиқловчи холат мухим ахамиятга эга. Ижобий хислатга эга қахрамон-мутафаккирлар икки кичик турга бўлинган: булар мулохаза юритувчиқахрамонлар (улар ер юзида харакат қилишади ва бир лахзага бир нуқтада тўхтаб, яна чексиз йўлларини давом эттиришади) ва арбобқахрамонлар. Мулохаза юритувчи қахрамонлар воқеаларнинг гувохлари бўлиб, уларнинг асосий хусусиятлари орасида, бўлаётган нарсаларга бефарқлик ва четланиш кузатилади. Улар фаолиятининг мотивацияси ёлғон қахрамонликнинг умумий пафосидан фарқ қиладиган ички, шахсий (ички) сабабларга боғлиқ. Мутафаккир-қахрамонлар инсоният фаровонлиги учун рухий туртки ва харакатни бирлаштиради. Бу қахрамонларнинг асосий характер хусусиятлари орасида илхомлантирувчи, ижодий туртки, фаолиятга чанқоқликдир. Асарда ажойиб предметни излаш келин излаш мотиви билан бирлаштирилган. Хикояларда иккита эртак мотиви: келин излаш ва куёвнинг келин томонидан синов қилиниши курашрақобат мотиви билан узвийлаштирилган. Тадқиқот натижаси - халқ анъаналари билан боғлиқ бўлган ва ёзувчининг индивидуал муаллифлик услубининг хусусиятларини ўзида мужассам этган "Платонов одами" қахрамонинингхусусиятларини таснифлашдан иборат. 
Калит сўзлар: қисса; фольклор анъанаси; эртак жанри; учинчи ўғил; паст қахрамон; антагонист; қахрамон характерининг фольклор типи; стереотиплик.

Abstract. The subject of the following study is folklore traditions in the works of A. Platonov. Fairy-tale elements were revealed in the process of analyzing the writer's stories. A unique, Platonic type of character of the hero is formed in the novels of the writer ("Platonic man") due to recurring elements. In particular, among the folklore features, the connection with the fabulous third son is noted. The characters in the presence of which the features of the fabulous third son is noted were conditionally attributed to the type of "eccentric craftsman". It is a hero endowed with creative talent to contemplate and create wonderful things. The life of the heroes-craftsmen is often associated with the motif of wandering. During the analysis, the type of "hero-thinker" with a positive and negative charge was identified. This division is determined by the criterion of the significance of what the hero does for others: thinking for the good or for the evil of a person. The concepts of "duma" and "mind" appear in the story with a negative characteristic. At the same time, for A. Platonov, the moment of affirming the instability of the border between a good and an evil act is important. The type of a thinking hero with a positive charge was divided into two subtypes - these are contemplative heroes (they move along the earth for short moments stopping at a particular point and again continuing their endless path) and action heroes. The heroes are contemplators - witnesses of events, among the main features of which are detachment and disinterest in what is happening The motivation of their activities is due to internal, personal (intimate) reasons, contrasting with the general pathos of false heroics. Heroes-figures combine a spiritual impulse and action for the benefit of humanity. Among the main character traits of these heroes is an inspired, creative impulse, a thirst for activity. The search for a wonderful object is combined in the stories with the search for a bride. There are two fairy-tale motifs in the stories the search for the bride and the test of the groom by the bride, combined with the motive of struggle-competition. The result of the study was the identification of a special type of hero - the "Platonic man", correlating with the folklore tradition and embodying the features of the individual-author's style of the writer.

Keywords: story; folklore tradition; fairy tale genre; third son; low hero; antagonist; folklore type of hero's character; stereotype.

Введение. Духовный потенциал платоновского слова, языка, повествования, текста невыразимо высок. В качестве главного художественного открытия писателя некоторые исследователи выделяют «освобождение внутриатомной энергии фразы», то есть момент, когда «сама фраза, предложение становится как бы маленьким художественным произведением» $(19,183)$. С. Семенова в отношении платоновского текста вводит понятие «мысле-слово», наделяя писателя индексом «самый метафизический». Понятие «метафизический» исследователь определяет следующим образом: «...всматривается он, в какие-то заповерхностные разрезы человеческого существования. Причём очень настойчиво и даже както маниакально» $(21,319)$. А в заключительной части своего труда С. 
Семенова определяет стиль писателя как «глубоко аналитический» $(21,375)$. Подобную характеристику платоновского текста делает С. Бочаров $(4,249)$.

Своеобразен взгляд И. Бродского на повествование А. Платонова. В поэтически выразительном тексте статьи, в качестве главного тезиса И. Бродский выдвигает подчинительный характер связи между писателем и эпохой, между платоновским повествованием и языком утопии и вводит понятие «грамматическая зависимость» $(5,272-273)$. Необходимо отметить, что к созданию предисловия к роману «Котлован» (появление этого произведения на литературной арене России и Запада стало событием значительным и знаковым) И. Бродский подошел не только как художник, наследовавший лучшие традиции русской классической литературы, не только как поэт (с гражданским началом, доминирующим в произведениях), остро чувствующий и часто трагически переживающий общение с веком, но и как исследователь. Поэтичность, страсть и внутренняя энергия, создающие общий тон статьи, не перекрывают желания автора-поэта привнести в анализ философские, лингвистические, литературоведческие штрихи. В этом нам видится несомненная ценность данного критического произведения И. Бродского для платоноведения.

Примечателен и тот факт, что другой творческий деятель, современник А. Платонова - М. Горький (ярчайшая культовая фигура литературы и критики начала XX века) неизменно высоко отзывался о языке молодого писателя, своего собрата по перу. «И бесспорно то, — писал М. Горький, что вы обладаете очень своеобразным языком» $(3,180)$. С. П. Залыгин, предваряя публикацию «Котлована», указывает на самобытность, неповторимость слова А. Платонова, составляющего «настоятельную необходимость для человека любой национальности, если он стремится к пониманию человечества» $(17,50)$. Лев Шубин - один из лучших исследователей творчества А. Платонова - раскрывает глубинную, философскую сущность диалогических отношений в тексте писателя $(28$, 107).

Уклоняясь от стиля Платонова, его вполне оригинальной «грамматики языка» (с характерным для писателя плеоназмом, парадоксом, анаколуфом, языковым ляпсусом и т.д.), исследователи говорят о тексте как определенном наборе знаков, формирующих код, требующий дешифровки. При этом смысл уходит за рамки собственно произведения, соединяясь с эпохой, литературным процессом, шире - культурой, историей, «грамматика» же определяется как граница, отправная точка для безграничного полёта мысли. Ю.М. Лотман говорит о возможности рассмотрения художественного текста «как текста многократно закодированного»: «Свойство художественных текстов превращаться в коды - моделирующие системы - приводит к тому, что некоторые признаки, специфические именно для текста как такового, в процессе художественной коммуникации переносятся в сферу кодирующей системы» $(9,65)$.

В этом плане весьма показательны, красноречивы размышления А. Шинделя о причинах «непохожести» А. Платонова. Исследователь пытается подобрать ключ к исключительности платоновского повествования, пытается выяснить, что заставляет выделять писателя «из ряда» других, «рассматривать его как некое крупное, но достаточно автономное в литературе явление» $(27,207)$. Определяя Платонова как «несомненного классика», А. Шиндель задается вполне закономерным вопросом: насколько правомерны, методически обоснованы дальнейшие исследования платоноведов, неоднократно предпринимающиеся ими попытки «вписать» 
писателя в русскую классику (вписать изнутри, а не декларативными рассуждениями). «Нужно ли это делать вообще? Не выморочное ли, не схоластическое ли это занятие?» - вопрошает исследователь и завершает свою мысль весьма категоричным утверждением: «Ни в коей мере. Это нужно не Платонову. Это необходимо нам, чтобы не оказаться вне Платонова. Мы были вне Платонова многие десятилетия по чисто политическим мотивам. У нас просто не было доступа к нему. Теперь доступ есть. Поэтому есть потребность соотнести его творчество с определенной шкалой высших культурных ценностей» $(27,207)$.

На современном этапе развития платоноведения наибольший интерес представляет проблема стереотипности как организующего начала платоновского текста, как одна из характерных черт творчества. Она наличествует в той или иной мере во всех платоновских жанрах, воздействует на самые различные аспекты творчества писателя и так или иначе отмечается большинством исследователей. Л. В. Карасёв говорит о постоянном наборе образов-мотивов у Платонова, называя самого писателя однообразным-одноо'бразным $(8,20)$. Этот факт подтверждается в исследованиях С. Семёновой и М. Ю. Михеева (22).

На научной конференции, посвященной 90-летию со дня рождения Андрея Платонова, в круг наиболее важных проблем платоноведения вошла проблема «постоянного» у писателя (Н. М. Малыгина рассматривает постоянные образы-символы, образующие сквозные сюжеты (10), В. Ю. Вьюгин рассматривает постоянные мотивы через призму романа «Чевенгур») $(13,258)$.

Истоки этой проблемы мы находим в словах самого Платонова: «Мои идеалы однообразны и постоянны. Я не буду литератором, если буду излагать только свои неизменные идеи, меня не станут читать. Я должен опошлять и варьировать свои мысли, чтобы получились приемлемые произведения. Именно - опошлять! А если бы я давал в сочинения действующую кровь своего мозга, их бы не стали печатать» $(1,166)$.

В плане стереотипности (повторяемости) особенно щедрой является повесть Платонова, представляющая исследователям богатый и разнообразный материал, демонстрирующий удивительные сходства, иногда даже совпадения в произведениях писателя.

Но исследование стереотипности (и как следствие этого систематизация платоновских произведений с помощью указателей образов, мотивов, сюжетов) не есть самоцель нашего исследования: наличие некой «глобальной общности», т.е. присутствие тех или иных элементов стереотипности на всех уровнях структуры повествования Андрея Платонова принимается нами как данность, не требующая дальнейших доказательств. Наша цель - определение причины появления стереотипности в творчестве Платонова; открытие источника, который, собственно и ограничивает свободу платоновского повествования; рассмотрение стереотипности как неотъемлемой части художественного метода писателя и как одной из центральных категорий в его философской системе.

Отметим также вопрос об оригинальности. Исключает ли стереотипность повести ее оригинальность? Разумеется, нет, напротив, то значительное место, которое занимают стереотипные элементы в жанре повести, позволяет говорить о том, что стереотипность разъясняет нам вопрос об оригинальности.

Основная часть. У повести Платонова совершенно особая связь с фольклором и, в первую очередь, с жанром сказки. Упоминания о фольклорной основе творчества писателя в сказочном аспекте находим в исследованиях В. Чалмаева, А. Каменского, М. Ю. Михеева, В. Аникина, 
В. Васильева (26). Последний называет подход писателя к сказочному жанру «мировоззренческим», отмечая следующее: «Фольклор для А. Платонова никогда не был детским чтением, развлекательной волшебной поэзией, он читал те же народные сказки как реалист, ученый, с глубоким знанием исторической и духовной работы прошлых поколений, стоящей за каждым персонажем или сюжетным поворотом незатейливой небылицы...Лучшие произведения А. Платонова рождены народным миропониманием, исходят из него и возвращаются к нему...Эти качества сообщают произведениям писателя достоинство сказки, не неправды, а высшего идеального искусства, прозревающего дали народной судьбы» $(6,175)$. Отметим, что в 1950 году в сборнике «Волшебное кольцо» в пересказе А. Платонова вышли семь сказок (7).

Фольклорный элемент в платоновском повествовании - это не литературный и умозрительный прием писателя, приобретенный им в долгом размышлении, но феномен, обеспеченный конкретной исторической реальностью. Обратимся к третьей строке автобиографического письма писателя: «Деревню же я до слез любил, не видя ее до 12 лет». «Любил, не видя» - речь, безусловно, идет о «внутреннем зрении», но в чем оно выражается, Платонов сформулирует в 1938 году: «Мертвые, - скажет писатель, — не чувствуют нашей любви к ним. И все же без них - без наших отцов и учителей - наша жизнь была бы невозможна ни в физическом, ни в духовном смысле. Поэтому правильное этическое отношение к нашим предкам и предшественникам, всякая память о них, имеет глубокое прогрессивное значение. Без связи с ними (в смысле продолжения их исторического дела), без живой памяти о них люди могли бы заблудиться на протяжении одного текущего века и озвереть: человеческий мир может быть построен лишь союзом многих поколений» $(6,173)$.

Проблему связи художественного мышления писателя с фольклорным наследием можно свести к следующим положениям: 1. степень творческого заимствования и наследования Платоновым мотивов, образов, поэтики фольклора очень высока (народное поэтическое творчество воспринимается Платоновым с позиций писателя и ученого), 2. через понятие «живой памяти» писатель вводит себя и свои произведения в общую систему устного народного поэтического творчества, «растворяясь» в народной массе, приобщаясь к безграничному жизненному опыту, получая право на бессмертие, 3. главная художественная задача писателя - сохранение «памяти жанра», который является, по емкому выражению М. М. Бахтина, «представителем творческой памяти в процессе литературного развития» (2, 142).

Основная часть. В творчество самого писателя фольклор входит в первую очередь в образе фольклорного третьего сына (третьего подчеркивает сам Платонов). «Особенно интересною представляется нам роль младшего из трех братьев, действующих в сказке, - пишет А.Н. Афанасьев. - Большая часть народных сказок, следуя обычному эпическому приему, начинается тем, что у отца было три сына: два - умные, а третий дурень. Старшие братья называются умными в том значении, которое придается этому слову на базаре житейской суеты, где всякий думает о своих личных интересах; а младший - глупым, в смысле отсутствия в нем этой практической мудрости: он простодушен, незлоблив, сострадателен к чужим бедствиям до забвения собственной безопасности и всяких выгод... Народная сказка... всегда на стороне нравственной правды, и по ее твердому убеждению выигрыш постоянно должен оставаться за простодушием, 
незлобием и сострадательностью меньшего брата» (12, 390). Под это определение подходят все главные герои платоновских повестей. Тип героя, испытывающего влияние сказочного третьего сына, будет условно назван нами «чудаком-умельцем».

Так, например, главный герой повести «Ямская слобода» живёт исключительно для других. За что и прозван окружающими «дурным». К типу «чудака-умельца» относится и Захар Павлович - герой повести «Происхождение мастера». Это был человек «...с тем зорким и до грусти измождённым лицом, который всё может починить и оборудовать, но сам прожил жизнь необорудованно. Любое изделие, от сковородки до будильника, не миновало на своём веку рук этого человека. Не отказывался он также подкидывать подмётки, лить волчью дробь и штамповать поддельные медали для продажи на сельских старинных ярмарках. Себе же он никогда ничего не сделал - ни семьи, ни жилища» $(16,531)$.

Герой повести - мастер по созданию замечательных, но «ненужных вещей»: «В зимние вечера он иногда делал ненужные вещи: башни из проволоки, корабли из кусков кровельного железа, клеил бумажные дирижабли и прочее - исключительно для собственного удовольствия. Часто он даже задерживал чей-нибудь случайный заказ, - например, давали ему на кадку новые обручи подогнать, а он занимался устройством деревянных часов, думая, что они должны ходить без завода - от вращения Земли» $(16,531)$. Или, например, Захар Павлович делал из дерева сковородку «...наливал...воды и достигал на медленном огне того, что вода кипела, а сковородка не горела...» $(16,532)$. К героям-чудакам, создателям замечательных вещей, годных для людской пользы, принадлежит и Бертран Перри («Епифанские шлюзы»). Герой продолжает ощущать чудесное вокруг себя даже в самый страшный момент своей жизни, находясь в камере смертников.

Ещё один герой-умелец - Егор Кирпичников, которого вполне правомерно назвать потомственным мастером, так как в повести представлен целый научный род изобретателей. Более того, героев данной повести можно представить как трёх сказочных братьев, где Егор является третьим, меньшим и самым удачливым. Чудачество же его заключается в неутомимости мысли. Решив научную проблему эфирного тракта, он не останавливается на достигнутом, а движется далее: «Только бродя по земле, под разными лучами солнца и над разными недрами, я способен думать. Я теперь понял отца. Нужны внешние силы для возбуждения мыслей. Эти силы рассеяны по земным дорогам, их надо искать и под них подставлять голову и тело, как под ливни...меня гонят вперёд мои беспокойные ноги и моя тревожная голова...» $(16,398)$.

В данной характеристике героя можно усмотреть родство со сказочной присказкой: «Поди туда — не знаю куда, принеси то — не знаю что», которая обычно предлагается сказочному герою как невыполнимое задание и носит ярко выраженный негативный характер, так как часто исходит от недругов (соперников), желающих устранить героя с пути, и предполагает в конце этого пути его гибель (в повести негатив отсутствует, хотя можно говорить о том, что он заменён своего рода нетерпением ожидающего молодого и даже ещё ненародившегося поколения, которое при определенных условиях может провоцировать негативную реакцию. Именно так происходит в случае отношений Попова и Кирпичникова - представителей старшего научного поколения. С другой стороны, в этом есть суть философии жизни. Наличие у каждого своей функции после её выполнения требует перехода героя на другую ступень развития, которая не есть смерть, но другая ступень в познании мира и человека). 
В контексте сказки данную установку повести можно рассматривать следующим образом: героя посылают на поиски старшие по роду (это его отец Михаил Кирпичников и основатель научной династии - Фаддей Попов - они оба могут быть отнесены к образу сказочного царя или братьев героя). Таким образом, герой оказывается в типичном для сказки «безвыходном» положении: он должен идти в свой, третий черёд и принести заказанное или не вернуться вовсе. Безысходность сказочная, не допускающая самоволия героя, есть граница или традиционность (в данном случае это выражается в определённом типе поведения героя в предложенных обстоятельствах).

В соответствии с развязкой большинства волшебных сказок герой повести, не достигая цели, гибнет, причём в случае гибели Попова и Егора Кирпичникова присутствует бутылочка со смертельным зельем и вода (снег), которая должна героя оживить после наступления смерти: 1. «...Он нашёл пузырёк с недопитым розовым ядом...» (гибель Попова), «...Снег его заметал всё глубже, и ноги уже укрыло совсем...» (оживление Попова); 2. «...В эту минуту непроницаемый едкий газ затянул всё судно...» (гибель Михаила Кирпичникова), «...отвлечённая могила под дном океана не давала веры в настоящую смерть...» (оживление Михаила Кирпичникова); 3. «...так как Кирпичников не мог идти на виселицу, валяясь в предсмертном бреду, то ему дали яду...» (гибель Егора Кирпичникова), «...Труп его был брошен в илистые воды Амазонки и смыт в Тихий океан...» (оживление Егора Кирпичникова).

Можно провести параллель со «Сказкой о серебряном блюдечке и наливном яблочке», где главная героиня Алёнушка была убита завистливыми сёстрами и затем оживлена родителями. Последние попросили живой воды у древней старушки. Или, например, в сказке «Иван-царевич и серый волк» братья убивают Ивана-царевича, забирая добытых им Жар-птицу, златогривого коня и невесту Елену Прекрасную. Оживляет героя серый волк, нашедший живую и мёртвую воду $(20,98,198)$.

В качестве специфических черт фольклорного третьего сына E.M. Мелетинский (исследователь использует термин «низкий герой») называет варьируемость героя между пассивностью (например, лень Емели-героя сказки «По щучьему велению») и удачливостью, умом (например, в образе Иванушки могут сочетаться героизм и комизм, герой варьируется между подлинным глупцом и «дурачком»-хитрецом $(11,326)$.

Указанное явление варьирования наблюдается в повестях А. Платонова у героя, условно названного «героем-думальщиком» и обладающего положительным и отрицательным зарядом. Такое деление обусловлено критерием значимости совершаемого героем для окружающих, т.е., другими словами, дума во благо или во зло человека. Ко второму типу можно отнести Шмакова, героя повести «Город Градов». Понятия «дума» и «ум» выступают в повести с отрицательной характеристикой. Это связано с пассивностью героя, его абсолютной «незаинтересованностью» в происходящем. При этом для А. Платонова важен момент утверждения зыбкости границы между добрым и злым поступком.

Шмаков лишь утверждается как герой-преобразователь, имеющий чёткое практическое задание: «врасти в губернские дела и освежить их здравым смыслом». На деле же - это «бумажный человек», проповедующий новое учение, где главный объект поклонения - бумага (бумага в его интерпретации становится антонимом природы: «Самый худший враг порядка и гармонии, - думал Шмаков, — это природа. Всегда в ней чтонибудь случается...»): «Бумага лишь символ жизни, но она и тень истины, а 
не хамская выдумка чиновника. Бумага, изложенная по существу и надлежаще оформленная, есть продукт высочайшей цивилизации...Более того, бумага приучает людей к социальной нравственности, ибо ничто не может быть скрыто от канцелярии... Канцелярия является главной силой, преобразующей мир порочных стихий в мир закона и благородства» (16, 463). Погибает герой от своего извращённого, перевёрнутого, словно в кривом зеркале, хода мыслей: «Шмаков через год умер от истощения на большом социально-философском труде: «Принципы обезличения человека, с целью перерождения его в абсолютного гражданина с законно упорядоченными поступками на каждый миг бытия» $(16,468)$.

Тип героя-думальщика, обладающий положительным зарядом, можно разделить на два подтипа: это герои-созерцатели (они движутся по земле на короткие мгновения останавливаясь в том или ином пункте и вновь продолжая свой бесконечный путь) и герои-деятели. Героев-созерцателей сам Платонов называет «свидетелями героических, трогательных и печальных событий»: свидетелями, но не участниками. Отличительная черта данных героев в отстранённости от основного корпуса происходящих событий. Несмотря на то что, например, Пухов принимает участие в военных действиях, Вощев роет котлован, а «некий душевный бедняк» из повести «Впрок» чинит солнце, они остаются внутренне равнодушны к своим поступкам (в этом сходство со сказочным Емелей) и всеми силами стремятся «не запачкать мозги» посторонней информацией: «Пухов, ты бы хоть в кружок записался, ведь тебе скучно! — говорил ему кто-нибудь. — Ученье мозги пачкает, а я хочу свежим жить! - иносказательно отговаривался Пухов... - Оковалок ты, Пухов, а ещё рабочий! - совестил его тот» (16, 504). К данному типу можно отнести трёх героев - это Фома Пухов («Сокровенный человек»), Вощев («Котлован»), душевный бедняк («Впрок»).

Обратимся к слову «оковалок», которое очень ёмко характеризует героя и явление вариативности, через которое осуществляется его связь с фольклорным «низким героем». «Валок - скошенная трава или скошенный хлеб, лежащие ровным рядом» (24), оковалок можно объяснить и как обрубок, т.е. подчёркивается отстранённость героя от общего действия. Данное слово не просто характеристика, но оскорбление, слово-обвинение. Для своих современников Пухов - отщепенец. С другой стороны, не придерживающийся общей линии поведения Фома Пухов обладает своей целью, а следовательно, неким высшим, сокровенным, открывающимся лишь немногим, знанием. И что самое главное - инакомыслие героя не отдаляет его от людей (платоновский герой - не лишний человек), а, напротив, ставит на путь служения, в случае Пухова, апостольского.

В качестве героев-деятелей определим Назара Чагатаева («Джан») и Николая Вермо («Ювенильное море»). Данные герои действуют на благо окружающих, причём достаточно стремительно. Источник правильного понимания повестей Платонова 30-х годов генетически восходит к проблеме взаимодействия литератур, решение которой позволяет раскрыть подлинную сущность психологии творчества писателя, которая заключается в органичном сплетении славянской и восточной волшебной сказки. Если в повести «Ювенильное море» преобладает влияние славянской сказки, то в повести «Джан» - восточной. Подобно предыдущим чудакам-умельцам Николай Вермо изобретает для нуждающегося человечества необходимые для жизни вещи. Одной же из чудесных идей Вермо был поиск Ювенильного моря: «Вермо в увлечении рассказывал пастуху, что внизу, в темноте земли, лежат навеки погребённые воды. Когда шло создание земного шара и теперь, когда оно продолжается, то много воды было зажато кристаллическими 
породами, и там вода осталась в тесноте и покое...» $(15,327)$. Кроме всего прочего, Вермо был музыкантом, создавая удивительную, завораживающую музыку, которая была «...проста и мучительна, близкая по выразительности к произношению яростных слов...» $(15,313)$.

Назар Чагатаев (герой повести «Джан») очень похож на Вермо - это тип активного героя, который творит благо, преодолевая ради этого любые препятствия. Со сказочным типом Иванушки данных героев связывает женский образ. Примечателен тот факт, что только эти два героя сосуществуют рядом с женщиной. Более того, с ней связано совершение ими поступков. Поскольку «Джан» - повесть восточная, то имеет смысл провести параллель с восточной сказкой. В повести несколько женских образов, которые в равной степени связаны с героем.

Для восточных сказок данный элемент является весьма характерным (его можно обозначить как эффект гарема). В восточных сказках часто действуют или три сестры, или три прекрасные пери. Например, в сказке «Дочь бедняка» содержатся три рассказа трёх пери $(25,426-440)$. Для сказок обычной является ситуация, в которой герой, для того чтобы соединиться с возлюбленной, должен преодолеть ряд препятствий. Чагатаев влюбляется в Ксеню с первого взгляда: «- Нет, скажи: ты сейчас влюбился в Ксеню? Я заметила. - Влюбился, - ответил Чагатаев, - я не вытерпел... - Ксеня тебя тоже полюбит...Я воспитаю её, внушу ей память о тебе, сделаю из тебя героя... - Я знаю, ты будешь счастлив, у тебя чистое сердце. Возьми тогда к себе мою Ксеню...» $(16,579-580)$. Герою обещается молодая жена, после чего он отправляется в долгий путь, в далёкую страну, чтобы вернуться победителем. Таким образом, обретение героических черт мы рассматриваем как сказочное условие или задание.

Путь Назара Чагатаева был действительно долог и сложен, а само пространство пустыни, по которой герой продвигается, наполнено сказочными существами. Чагатаев встречает сказочного старичка Суфьяна, который помогает герою, указывая дорогу к народу джан. В повести «Ювенильное море» Вермо тоже попадается старичок, но, в отличие от Суфьяна, он выполняет функцию антагониста (его можно сравнить со сказочным лешим). Чагатаев минует страшных существ, похожих на птиц, и вступает в битву с властелином тёмных сил (Нур-Мухаммед), побеждая и освобождая из заточения людей, среди которых находится и его мать. В финале повести Назар Чагатаев возвращается к своей наречённой невесте Ксене: «Чагатаев взял руку Ксени в свою руку и почувствовал дальнее поспешное биение её сердца, будто душа её желала пробиться оттуда к нему на помощь. Чагатаев убедился теперь, что помощь к нему придёт лишь от другого человека» $(15,559)$.

Возлюбленная Николая Вермо - Надежда Босталоева. Они полюбили друг друга, оказавшись «нечаянно рядом». Главное сказочное задание для героя - соответствовать своей наречённой невесте, которая была назначена директором нового мясосовхоза, где Вермо назначен главным инженером. Здесь действует механизм сказки, где героиня, не уступая мужскому персонажу ни в силе, ни в уме, часто выходит с ним на бой. Можно обратиться к сказке про Прекрасную Василису Микулишну, героиня которой ради спасения мужа из плена переодевается в мужское платье, отрезает русые косы и вступает в противоборство с обидчиком, с самим князем Владимиром $(20,28)$.

Чем инициативнее становится Вермо, тем сильнее его любит Босталоева: «— Товарищ Босталоева, — сказал Вермо, — давайте покроем 
всю степь, всю Среднюю Азию озёрами ювенильной воды! Мы освежим климат и на берегах новой воды разведем миллионы коров! Я осознаю всё ясно! - Давайте, Вермо, - ответила Босталоева. — Я любить буду вас» (15, 326). В финале повести герои уплывают на корабле в командировку как равные, «чтобы проверить...в опытном масштабе идею сверхглубокого бурения вольтовым пламенем и научиться добывать электричество из пространства, освещённого небом» $(15,368)$.

Выводы. Полученные в ходе наблюдений над литературными взаимодействиями повестей А. Платонова со славянской и восточной сказкой данные позволяют сделать вывод о синтезе духовного и собственно литературного импульсов, которые исходят от фольклорного материала и воздействуют на писателя. Словацкий компаративист Д. Дюришин рассматривает импульс как особую форму влияния $(23,323)$. Результатом такого воздействия является появление новой (платоновской) художественной системы, которая содержит фольклорные принципы организации структуры повествования. Речь идёт о явлении стереотипности, которое свойственно фольклорным произведениям. Выражается данное явление в устойчивости отдельных элементов текста и в их переходе в неизменном виде из одного произведения в другое, и указывает оно в первую очередь на жанровую принадлежность текста.

Поскольку повесть А. Платонова связана с жанром сказки, то и принцип стереотипического восприятия повествования наследуется именно от этого жанра. Например, для волшебных сказок характерно наличие семи основных героев (В.Я. Пропп). В соответствии с концепцией В.Я. Проппа функции логически объединяются по кругам, которые в целом соответствуют исполнителям: исследователь выделяет семь сказочных кругов - круг действий антагониста, дарителя, помощника, царевны, отправителя, героя, ложного героя (18). А для жанра сказки в целом характерно наличие ведущего образа, называемого «третьим сыном», или «низким героем» (М.Е. Мелетинский).

Подобно тому, как в сказке идентификация по жанровому признаку может проводиться через уровень образной системы и сводиться к наличию основного героя или набора героев, в платоновском повествовании, на уровне образной системы, наблюдается сходство главных героев, их подчинённость одной цели и идее. Именно этот фактор позволил создать классификацию фольклорного типа героя, где каждый герой повести входит в структуру фольклорного образа «третьего сына». Терминологически данный феномен можно обозначить как «платоновский человек».

«Платоновский человек» - основной герой платоновского повествования (во внимание принимаются только повести писателя), генетически восходящий к сказочному герою, содержащему основные черты «третьего сына» и концентрирующего в себе сказочную энергетику. Фольклорное начало «платоновского человека» не исключает оригинальности его исполнения, своеобразия авторской позиции. Как продолжатель фольклорной жанровой традиции (сказка - сказание повествование - повесть) Андрей Платонов - один из многих, кто сохраняет традицию, служит ей. Но удивительная точность, с которой выписан герой, совмещающий несколько, подчас разнонаправленных, характеристик, балансирующий на грани добра и зла, - это шедевр, соответствующий именно платоновскому повествованию. «Платоновский человек» - конечная цель в решении проблемы восточно-славянского сказочного синтеза в платоновском повествовании, он есть результат данного синтеза, многосложная динамическая макросистема, отражающая глубинные процессы межлитературности, способствующая реализации функции 
комплементаризации. В теории межлитературности широко используется наряду с понятиями интеграционной и дифференциационной функций межлитературного процесса понятие комплементарной, т.е. взаимодополняющей функции $(14,7)$.

\section{Использованная литература}

1. «Живя главной жизнью» (А. Платонов в письмах к жене, документах и очерках ) /Волга. — 1975. — № 9. - С. 160-178.

2. Бахтин М.М. Проблемы поэтики Достоевского. - 2-е изд., перераб. и доп.

- Москва: Сов. писатель, 1963. - 363 с.

3. Боровой Л. Язык писателя. - М., 1966. - 220 с.

4. Бочаров С. О художественных мирах. - М.: Сов. Россия, 1985. - 296 с.

5. Бродский И. Поклониться тени. - Л.: ТЕРРА, 2000. - 315 с.

6. Васильев В. Андрей Платонов. - М.: Современник, 1982. — 230 с.

7. Волшебное кольцо. Русские сказки. Пересказал А. Платонов. Под общей редакцией М. А. Шолохова. - М. - Л.: Детгиз,1950. - 462 с.

8. Карасёв Л.В. Знаки покинутого детства («постоянное» у Платонова) //Вопросы философии. - 1990. — №2. - С. 33-38.

9. Лотман Ю.М. Об искусстве. - Санкт-Петербург: Искусство, 1998. - 702 c.

10. Малыгина Н.М. Андрей Платонов: Поэтика «возвращения». - М.: Теис, 2005. - 334 c.

11. Мелетинский Е.М. Герой волшебной сказки. - М.: Наука, 1958. - 240 c.

12. Народные русские сказки А.Н. Афанасьева в 3 х томах. Том 3. - М.: Худож. литература, 1957. - 572 с.

13. Колесникова Е.И. Научная конференция, посвящённая 90-летию со дня рождения Андрея Платонова // Русская литература. - 1990. — № 2. C. 258-263.

14.Особые межлитературные общности - 5. - Ташкент: Изд-во ФАН АН $\mathrm{PУ}_{3}, 1993.261 \mathrm{c}$.

15.Платонов А. Государственный житель. Проза. Ранние сочинения. Письма. - Минск: Мастацкая літаратура, 1990. — 702 с.

16.Платонов А. Избранные произведения. Рассказы. Повести. - М.: Мысль, 1984. - $653 \mathrm{c}$.

17.Платонов А. Котлован // Новый мир. - 1987. — № 6. - С. 50-123.

18.Пропп В.Я. Морфология сказки. - М.: Наука,1969. - 168 с.

19.Русская литература XX века: взгляд из ситуации конца века ("Круглый стол" кафедры русской литературы XX века Литературного института им. А. М. Горького) //Лепта. - 1996. - № 28. - С. 181-211.

20. Русские сказки. - Т.: Ўқитувчи, 1986. - 400 с.

21.Семенова С. Преодоление трагедии: «Вечные вопросы в литературе». -

М.: Сов. писатель, 1989. - 440 с.

22. Семёнова С. Преодоление трагедии: «Вечные вопросы в литературе». М.: Сов. писатель, 1989. - 440 с.; Михеев М. Ю. В мир Платонова через его язык. Предположения, факты, истолкования, догадки. - М.: Изд-во МГУ, 2003. - 406 c.

23. Сравнительное изучение славянских литератур. Просвещение, 1973. - 511 с.

24.Толковый словарь русского языка /Под. ред. С.И. Ожегова и Н.Ю. Шведовой. - URL: $\underline{w w w . k m / r u}$ 
25. Узбекские народные сказки. - Ташкент: Ўқитувчи, 1963. 467 с. т.2; 462 c.

26. Чалмаев В. Андрей Платонов (К сокровенному человеку). - М.: Сов. писатель, 1989. - 448 с.; Примитив и его место в художественной культуре Нового и Новейшего времени. - М.: Наука, 1983. - 304 с.; Михеев М.Ю. В мир Платонова через его язык. Предположения, факты, истолкования, догадки. - М.: Изд-во МГУ, 2003. — 406 с.; Васильев В. Андрей Платонов. - М.: Современник, 1982. - 232 с.

27. Шиндель А. Свидетель (Заметки об особенностях прозы Андрея Платонова) //Знамя. — 1989. —№ 9. Сентябрь. — С. 207-217.

28.Шубин Л. Андрей Платонов //Вопросы литературы. — 1967. — № 6. C. $26-54$.

\section{References}

1. Volga, 1975, No. 9, pp. 160-178.

2. Bakhtin M.M. Problemy poetiki Dostoevskogo (Problems of Dostoevsky's Poetics), Moscow: Sov. pisatel', 1963, 363 p.

3. Borovoi L. Yazyk pisatelya (Writer's language), Moscow, 1966, $220 \mathrm{p}$.

4. Bocharov S. O khudozhestvennykh mirakh (About art worlds), Moscow: Sov. Rossiya, 1985, $296 \mathrm{p}$.

5. Brodskii I. Poklonit'sya teni (Bow to the Shadows), Leningrad: TERRA, 2000, $315 \mathrm{p}$.

6. Vasil'ev V. Andrei Platonov (Andrei Platonov), Moscow: Sovremennik, 1982, $230 \mathrm{p}$.

7. Volshebnoe kol'tso. Russkie skazki. Pereskazal A. Platonov (Magic ring. Russian tales. Retold by A. Platonov), Ed. M. A. Sholokhov, Moscow Leningrad: Detgiz, 1950, 462 p.

8. Karasev L.V. Voprosy filosofii, 1990, No. 2, pp. 33-38.

9. Lotman Yu.M. Ob iskusstve (About art), Saint Petersburg: Iskusstvo, 1998, 702 p.

10. Malygina N.M. Andrei Platonov: Poetika "vozvrashcheniya" (Andrey Platonov: The Poetics of the "Return"), Moscow: Teis, 2005, 334 p.

11. Meletinskii E.M. Geroi volshebnoi skazki (Heroes of a fairy tale), Moscow: Nauka, 1958, 240 p.

12. Narodnye russkie skazki A.N. Afanas'eva $>3$ kh tomakh (Folk Russian fairy tales by A.N. Afanasyev in 3 volumes), Vol. 3, Moscow: Khudozh. literatura,1957, $572 \mathrm{p}$.

13. Kolesnikova E.I. Russkaya literature, 1990, No. 2. pp. 258-263.

14. Osobye mezhliteraturnye obshchnosti - 5 (Special interliterary communities 5), Tashkent, 1993, $261 \mathrm{p}$.

15. Platonov A. Gosudarstvennyi zhitel'. Proza. Rannie sochineniya. Pis'ma (State resident. Prose. Early writings. Letters), Minsk: Mastatskaya litaratura, 1990, 702 p.

16. Platonov A. Izbrannye proizvedeniya. Rasskazy. Povesti (Selected works. Stories. Tale), Moscow: Mysl', 1984, 653 p.

17. Platonov A. Novyi mir, 1987, No. 6, pp. 50-123.

18.Propp V.Ya. Morfologiya skazki (Morphology of the fairy tale), Moscow: Nauka, 1969, 168 p.

19. Lepta, 1996, No. 28, pp. 181-211.

20. Russkie skazki (Russian tales), Tashkent: Uqituvchi, 1986, $400 \mathrm{p}$.

21. Semenova S. Preodolenie tragedii: "Vechnye voprosy v literature" (Overcoming Tragedy: "Eternal Questions in Literature), Moscow: Sov. pisatel', 1989, 440 p. 
22.Semenova S. Preodolenie tragedii: "Vechnye voprosy $v$ literature" (Overcoming Tragedy: "Eternal Questions in Literature), Moscow: Sov. pisatel', 1989, 440 p.; Mikheev M. Yu. V mir Platonova cherez ego yazyk. Predpolozheniya, fakty, istolkovaniya, dogadki (In the world of Platonov through his language. Assumptions, facts, interpretations, conjectures), Moscow: Izd-vo MGU, 2003, $406 \mathrm{p}$.

23.Sravnitel'noe izuchenie slavyanskikh literature (Comparative study of Slavic literatures), Moscow: Prosveshchenie, 1973, 511 p.

24.Tolkovyi slovar' russkogo yazyka (Explanatory dictionary of the Russian language)/Ed. S.I. Ozhegova i N.Yu. Shvedovoi //www.km/ru

25. Uzbekskie narodnye skazki (Uzbek folk tales), Tashkent: Ўқituvchi, 1963. 467 s. t.2; $462 \mathrm{~s}$.

26. Chalmaev V. Andrei Platonov (K sokrovennomu cheloveku) (Andrey Platonov (To the secret man)), Moscow: Sov. pisatel',1989, 448 p.; Primitiv $i$ ego mesto $v$ khudozhestvennoi kul'ture Novogo i Noveishego vremeni (The Primitive and Its Place in the Artistic Culture of Modern and Contemporary Times), Moscow: Nauka,1983, 304 p.; Mikheev M.Yu. V mir Platonova cherez ego yazyk. Predpolozheniya, fakty, istolkovaniya, dogadki (In the world of Platonov through his language. Assumptions, facts, interpretations, conjectures), Moscow: Izd-vo MGU, 2003, 406 p.; Vasil'ev V. Andrei Platonov (Andrei Platonov), Moscow: Sovremennik, 1982, $232 \mathrm{p}$.

27. Shindel' A. Znamya, 1989, No. 9, sentyabr', pp. 207-217.

28. Shubin L. Voprosy literatury, 1967, No. 6, pp. 26-54. 